\title{
Envenomation caused by Rhopalurus amazonicus Lourenço, 1986 (Scorpiones, Buthidae) in Pará State, Brazil
}

\author{
Deyanira Fuentes-Silva', Alfredo P Santos- $-\mathrm{r}^{2}$ and Joacir Stolarz Oliveira ${ }^{3^{*}}$
}

\begin{abstract}
Scorpions, mainly those belonging to the genus Tityus cause many deaths and injuries in Brazil, with tens of thousands of envenomations notified every year. However, injuries involving other scorpion species are scarcely registered. Among the sixteen species of the genus Rhopalurus, Thorell, 1876, described up to date, nine are found in this country, with only a confirmed case of human envenomation provoked by R. agamemnon Koch, 1839. The present case reports, for the first time, a case of scorpion sting in a human victim involving Rhopalurus amazonicus, endemic species of the west region of the Pará state, Amazon, Brazil. The symptoms of envenomation were local pain and paresthesia. This study contributes to develop the knowledge on venomous scorpions, particularly those that may cause envenomations in this region.
\end{abstract}

Keywords: Scorpion sting, Rhopalurus amazonicus, Venomous animals, Envenomation, Brazilian Amazon, Pará

\section{Background}

It is known that scorpion envenomation comprises an important public health problem in Latin American countries, including Brazil, Cuba and Mexico [1-4]. According to the Brazilian Notifiable Diseases Information System (Sistema de Informação de Agravos de Notificação - SINAN), in 2013 almost eighty thousand cases of scorpion stings were registered in Brazil, which resulted in 75 deaths. To date, the states of Minas Gerais, São Paulo and Bahia have recorded the higher numbers of notifications concerning scorpion stings [5]. In those states, most envenomations are caused by Tityus serrulatus Lutz \& Mello, 1922, T. stigmurus Thorell, 1876 and T. bahiensis Perty, 1833. These three species belong to the family Buthidae and their stings may provoke a broad range of clinical effects such as cardiotoxicity, neurotoxicity, respiratory dysfunction and, ultimately, lead to death $[6,7]$.

In northern Brazil, Pará is the state where scorpion stings are more frequent and the species $T$. silvestris and

\footnotetext{
* Correspondence: jstolarz@ig.com.br

${ }^{3}$ Laboratory of Physiology and Animal Toxins (Fistox), Institute of Educational Sciences, Federal University of Western Pará (UFOPA), Av. Marechal Rondon, s/n, Caranazal, Santarém, Pará State CEP 68040-470, Brazil

Full list of author information is available at the end of the article
}

T. obscurus are responsible for the majority of cases. The latter, previously known as $T$. cambridgei or $T$. paraensis, is a big black scorpion, widely distributed in the Brazilian Amazon, particularly in Mato Grosso, Pará and Amapá states. It is considered the most important species responsible for human envenomations in those states [8-10].

According to the Brazilian Ministry of Health, the signs and symptoms of a scorpion sting may be classified as mild, with local pain and paresthesia; moderate, when there is sweating, nausea, occasional vomiting, tachypnea, tachycardia and mild hypertension; or severe when, in addition to the aforementioned symptoms, profuse and uncontrollable vomiting, intense sialorrhea, agitation, prostration, bradycardia, heart failure, pulmonary edema, shock, convulsions and coma are present. Death is attributed to the complications of pulmonary edema and shock [11]. These clinical manifestations fit in a more recent classification proposed by Khattabi et al. [12], in which mild, moderate and severe correspond respectively to Class I, characterized by local manifestations; Class II, that includes minor non-life-threatening manifestations; and Class III, when severe manifestations are observed, which at least include cardiac, respiratory or neurological failure. 
The envenomation caused by T. obscurus frequently leads to local manifestations such as pain followed by paresthesia, edema, erythema, and, to a less extent, general systemic manifestations mainly consisting of sweating, agitation, tremors, nausea and myoclonus $[8,13]$. Accidents involving other scorpion species are hardly notified, possibly because some victims develop only mild symptoms or healthcare services are not accessible by those who live in distant rural communities. Therefore, accidents involving different scorpion species, other than T. obscurus, are usually neglected or underreported cases.

Within of the Amazon forest, in Alter do Chão region, Pará state, the yellow scorpion Rhopalurus amazonicus is found, which also belongs to the family Buthidae (Figure 1). This endemic species was originally describe by Lourenço [14] and like other species of the genus Rhopalurus, it inhabits open Amazonian savannas, living under fallen tree trunks or under barks up to some meters above the ground. Furthermore, this species might be found inside houses.

According to Pardal et al. [8], the number of accidents provoked by the yellow scorpion in Santarém city, in the west of Pará state, was smaller than that caused by the species $T$. obscurus. Unfortunately, the authors did not mention the genus or the species of these yellow scorpions. This study is, to the best of our knowledge, the first description of an envenomation caused by the scorpion $R$. amazonicus in an adult man of 32 years who was handling these animals. The symptoms were local, around the sting area, and no other complications were observed.

\section{Case presentation}

A 32-year-old healthy male weighting $72 \mathrm{~kg}$ was stung by a scorpion on his right thumb while collecting these animals (Figure 2). The accident occurred in a savanna in the Tapari community, Santarém city, Pará state, Brazil

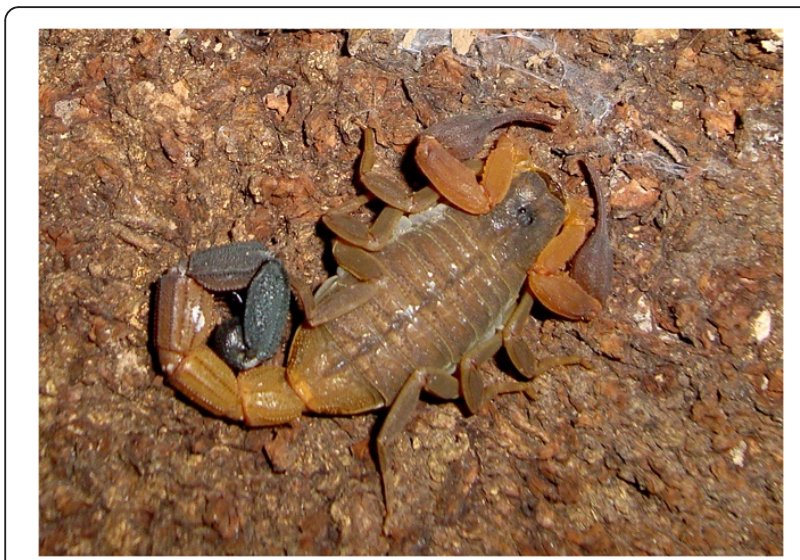

Figure 1 Adult female of Rophalurus amazonicus. $\left(02^{\circ} 26^{\prime} 54^{\prime \prime}\right.$ S; 54 53' 25” W) on October 17, 2013 (Figure 3). Previously, the species was identified as R. amazonicus by the arachnologist who originally described it, $\mathrm{Dr}$ Wilson R. Lourenço [14].

The victim described local pain similar to a bee or wasp sting immediately after the scorpion sting, which rapidly spread throughout his arm, together with paresthesia, remarkably numbness and tingly sensations, 30 minutes after. Subsequently, he had a slight swelling that started in the thumb and spread to the arm during the first 12 hours along with severe itching that consisted of a crawling sensation on his skin from the hand to the arm. Hence, treatment with antivenom was not necessary. Approximately 56 hours after the accident, local and systemic symptoms disappeared.

\section{Discussion and conclusions}

In Brazil, scorpion species of the genus Tityus are recognized as animals of medical importance, since they are responsible for high morbidity among adults as well as fatalities in children and the elderly. Studies on the symptoms and manifestations of envenomation caused by Brazilian Tityus are widely documented [1,6-11,13]. Nevertheless, accidents provoked by other species are rare or poorly reported in the literature, such as those caused by the genus Rhopalurus. Concerning this genus, up to date only three cases of human envenomation caused by Rhopalurus agamemnon have been described, all of them occurred in Piauí and Bahia states, in the Northeast region $[15,16]$. Among them, only the case registered in Bahia had the species confirmed because it was collected. The clinical symptoms of envenomation by $R$. agamemnon were classified as a mild envenomation or Class I with paresthesia, shaking hands, tingling tongue, and curiously the victim did not present local pain [16]. In contrast, the main symptoms of the envenomation caused by $R$. amazonicus were radiating pain from sting site, paresthesia and severe itching sensation. Confirmed cases of envenomation by the yellow scorpion $R$. amazonicus have not been reported up to this moment. However, in 2003 Pardal et al. [8] mentioned the occurrence of accidents caused by yellow scorpions from the Amazon region of Santarém, but its scientific name was not provided.

Pará state records the highest number of scorpion stings in the North region of Brazil. According to SINAN [5], in 2013 the number of cases in this state was 1,885 ( $54 \%)$ out of a total of 3,502 notifications registered for all seven states that comprise this region. In this concern, the notification of envenomation caused by venomous animals identified at least at the genus level still represents a gap in official data.

Herein, we presented the first report of an envenomation caused by $R$. amazonicus, an endemic species to 


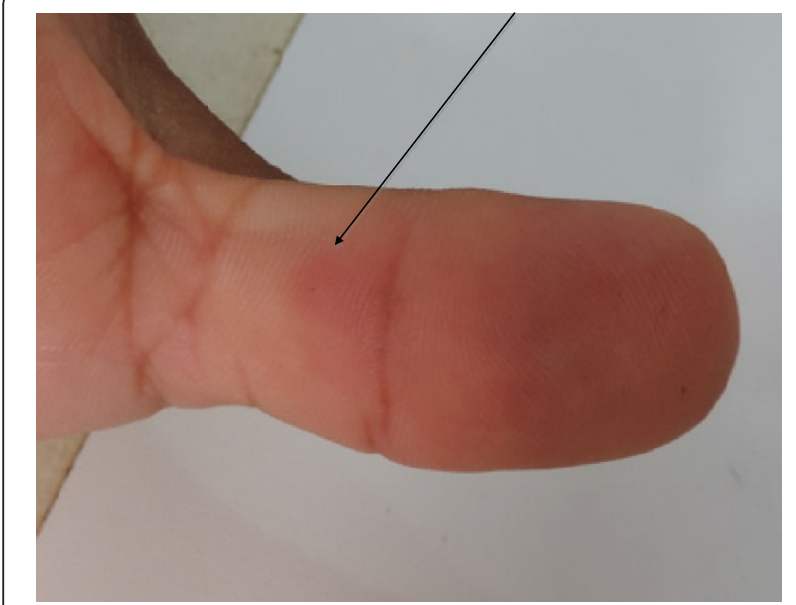

Figure 2 Scorpion sting site on the middle of the thumb 56 hours after the accident. the Amazon forest in Pará state, which, based on the symptoms, was classified as mild or Class I. However, it is known that symptoms provoked by envenomations depend on several factors such as the dose of venom injected, site of the sting, age, body mass and physiological conditions of the victim, being children and elderly the most vulnerable $[5,6,9,16,17]$. In conclusion, this report contributes to the knowledge on scorpion species capable of causing envenomations in Brazil. However, further study is required in order to evaluate the toxicity of this species on humans, which will make possible the classification of $R$. amazonicus as a scorpion of medical importance in the country.

\section{Consent}

Written informed consent was obtained from the patient for publication of this case report and any accompanying images.

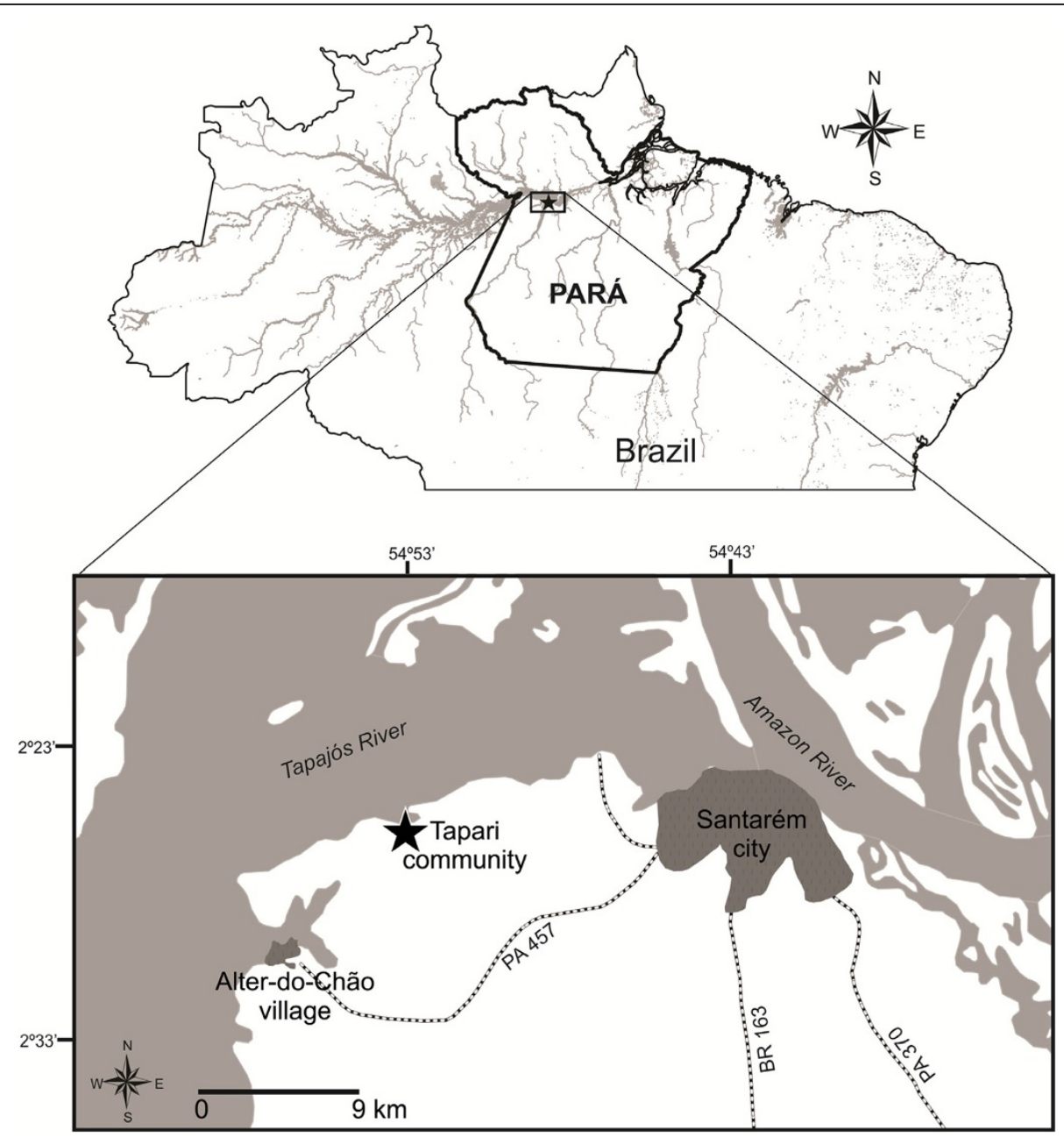

Figure 3 Map of the Pará state, in the northern Brazil. Inset emphasizes the hydrographic basin of the Tapajós river. The black star indicates Tapari, where the envenomation provoked by $R$. amazonicus occurred. Distance is shown on a relative scale bar. The map was created using the free software QGis 2.2. 


\section{Competing interests}

The authors declare that they have no competing interests.

\section{Authors' contributions}

DFS and JSO analyzed data and prepared the manuscript for publication. APS Jr helped in data acquisition and image processing. All authors read and approved the final manuscript.

\section{Acknowledgments}

The authors would like to thank Dr. W. R. Lourenço of the Muséum National d'Histoire Naturelle, Paris, France, for his help in the confirmation of Rhopalurus amazonicus species. This work was supported by the Coordination for the Improvement of Higher Education Personnel - CAPES (AUXPE 2165/2011).

\section{Author details}

${ }^{1}$ Laboratory of Chemistry and Biological Macromolecule Structure, Federal University of Western Pará (UFOPA), Santarém, Pará State, Brazil. '2Laboratory of Ecology and Animal Behavior, Federal University of Western Pará (UFOPA), Santarém, Pará State, Brazil. ${ }^{3}$ Laboratory of Physiology and Animal Toxins (Fistox), Institute of Educational Sciences, Federal University of Western Pará (UFOPA), Av. Marechal Rondon, s/n, Caranazal, Santarém, Pará State CEP 68040-470, Brazil.

Received: 18 September 2014 Accepted: 2 December 2014

Published: 9 December 2014

\section{References}

1. Bucaretchi F, Baracat ECE, Nogueira RJN, Chaves A, Zambrone FAD, Fonseca MRCC, Tourinho FS: A comparative study of severe scorpion envenomation in children caused by Tityus bahiensis and Tityus serrulatus. Rev Inst Med Trop São Paulo 1995, 37(4):331-336.

2. Garrote MNR, López RJL, Mesa EV, Rodríguez SIT, Pérez MCA: Sintomatología de la picadura del alacrán azul cubano Rhopalurus junceus. Rev Med Homeopat 2012, 5(1):7-12.

3. Rodríguez-Ravelo R, Coronas FIV, Zamudio FZ, González-Morales L, López GE, Urquiola AR, Possani LD: The Cuban scorpion Rhopalurus junceus (Scorpiones, Buthidae): component variations in venom samples collected in different geographical areas. J Venom Anim Toxins ind Trop Dis 2013, 19(1):13. doi:10.1186/1678-9199-19-13.

4. Bourée $P$, Frinot Joseph $P$, Fernot Joseph P, Gil REM, Fils-Aimé F, Barrera RR, Goyffon M: Les piqûres de scorpion: un problème de santé publique à Morelos (Mexique). Cahiers Santé 2005, 15(4):217-223.

5. Brazilian Notifiable Diseases Information System (Sistema de Informação de Agravos de Notificação - SINAN): Tabulação de dados. 2001 a 2006 e a partir de 2007. Acidente por animais peçonhentos. http://dtr2004.saude. gov.br/sinanweb/. Accessed on September 11 of 2014.

6. Barbosa AD, Magalhães DF, Silva JA, Silva MX, Cardoso MFEC, Meneses JNC, Cunha MCM: Caracterização dos acidentes escorpiônicos em Belo Horizonte, Minas Gerais, Brasil, 2005 a 2009. Cad Saúde Pública 2012, 28(9):1785-1789.

7. Brazil TK, Lira-da-Silva RM, Porto TJ, Amorim AM, da Silva TF: Escorpiões de importância médica do Estado da Bahia, Brasil. Gaz Méd Bahia 2009, 79(Suppl 1):38-42.

8. Pardal PPO, Castro LC, Jennings E, Pardal JSO, Monteiro MRCC: Aspectos epidemiológicos e clínicos do escorpionismo na região de Santarém, Estado do Pará, Brasil. Rev Soc Bras Med Trop 2003, 36(3):349-353.

9. Maestri Neto A, Guedes AB, Carmo SF, Chalkidis HM, Coelho JS, Pardal PPO: Aspectos do escorpionismo no Estado do Pará - Brasil. Rev Para Med 2008, 22(1):49-55.

10. Secretaria de Vigilância em Saúde: Departamento de Vigilância Epidemiológica: Manual de controle de escorpiões. Série B. Brasília: Ministério da Saúde; 2009.

11. Fundação Nacional de Saúde (FUNASA): Manual de diagnóstico e tratamento de acidentes por animais peçonhentos. $2^{a}$ edição. Brasília: Ministério da Saúde; 2001.

12. Khattabi A, Soulaymani-Bencheikh R, Achour S, Salmi LR, Scorpion consensus expert group: Classification of clinical consequences of scorpion stings: consensus development. Trans R Soc Trop Med Hyg 2011, 105(7):364-369.

13. Pardal PPO, Ishikawa EAY, Vieira JLF, Coelho JS, Dórea RCC, Abati PAM, Quiroga MMM, Chalkidis JM: Clinical aspects of envenomation caused by Tityus obscurus (Gervais, 1843) in two distinct regions of Pará State,
Brazilian Amazon basin: a prospective case series. J Venom Anim Toxins incl Trop Dis 2014, 20(1):3. doi:10.1186/1678-9199-20-3.

14. Lourenço WR: Biogéographie et phylogénie des scorpions du genre Rhopalurus Thorell, 1876 (Scorpiones, Buthidae). Mém Soc R Belge Ent 1986, 33:129-137.

15. Carvalho LS, Santos MPD, Dias SC: Escorpionismo na zona rural de Teresina, Estado do Piauí: relato de casos de envenenamento. Rev Soc Bras Med Trop 2007, 40(4):491.

16. Brandão RA, Françoso RD: Acidente por Rhopalurus agamemnon (Koch, 1839) (Scorpiones, Buthidae). Rev Soc Bras Med Trop 2010, 43(3):342-344.

17. Albuquerque CMR, Neto PLS, Amorim MLP, Pires SCV: Pediatric epidemiological aspects of scorpionism and report on fatal cases from Tityus stigmurus stings (Scorpiones: Buthidae) in State of Pernambuco, Brazil. Rev Soc Bras Med Trop 2013, 46(4):484-489.

doi:10.1186/1678-9199-20-52

Cite this article as: Fuentes-Silva et al:: Envenomation caused by Rhopalurus amazonicus Lourenço, 1986 (Scorpiones, Buthidae) in Pará State, Brazil. Journal of Venomous Animals and Toxins including Tropical Diseases 2014 20:52.

\section{Submit your next manuscript to BioMed Central and take full advantage of:}

- Convenient online submission

- Thorough peer review

- No space constraints or color figure charges

- Immediate publication on acceptance

- Inclusion in PubMed, CAS, Scopus and Google Scholar

- Research which is freely available for redistribution

Submit your manuscript at www.biomedcentral.com/submit
C BioMed Central 